\title{
HIGH LEVEL WASTE (HLW) SLUDGE BATCH 4 (SB4): SELECTING GLASSES FOR A VARIABILITY STUDY
}

K.M. Fox

T.B. Edwards

D.K. Peeler

July 2006

Process Science and Engineering Section Savannah River National Laboratory Aiken, SC 29808

Prepared for the U.S. Department of Energy Under Contract Number DEAC09-96SR18500

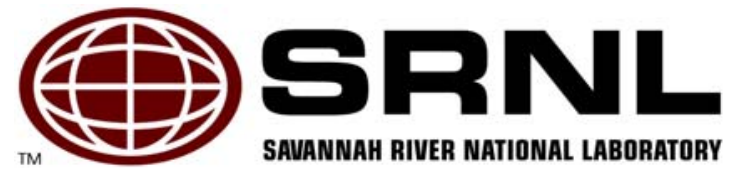


WSRC-STI-2006-00039

Revision 0

\section{DISCLAIMER}

This report was prepared by Washington Savannah River Company (WSRC) for the United States Department of Energy under Contract No. DE-AC09-96SR18500 and is an account of work performed under that contract. Neither the United States Department of Energy, nor WSRC, nor any of their employees makes any warranty, expressed or implied, or assumes any legal liability or responsibility for the accuracy, completeness, or usefulness, of any information, apparatus, or product or process disclosed herein or represents that its use will not infringe privately owned rights. Reference herein to any specific commercial product, process, or service by trademark, name, manufacturer or otherwise does not necessarily constitute or imply endorsement, recommendation, or favoring of same by WSRC or by the United States Government or any agency thereof. The views and opinions of the authors expressed herein do not necessarily state or reflect those of the United States Government or any agency thereof.

\section{Printed in the United States of America \\ Prepared For \\ U.S. Department of Energy}

The Savannah River National Laboratory is operated for the U.S. Department of Energy by Washington Savannah River Company. 
Keywords: high level waste, glass, SB4, variability, durability

Retention: permanent

\section{HIGH LEVEL WASTE (HLW) SLUDGE BATCH 4 (SB4): SELECTING GLASSES FOR A VARIABILITY STUDY}

K.M. Fox

T.B. Edwards

D.K. Peeler

July 2006

Process Science and Engineering Section Savannah River National Laboratory Aiken, SC 29808 


\section{REVIEWS AND APPROVALS}

\section{AUTHORS:}

K.M. Fox, Materials Science and Technology Section

Date

T.B. Edwards, Statistical Consulting Section

Date

D.K. Peeler, Process Science and Engineering Section

Date

TECHNICAL REVIEWER:

M.E. Smith, Process Science and Engineering Section

Date

APPROVERS:

R.E. Edwards, Manager, Process Science and Engineering Section

Date

C.C. Herman, Manager, Process Engineering Technology Group

Date

J.E. Occhipinti, Manager, DWPF Process Engineering

Date 
WSRC-STI-2006-00039

Revision 0

\section{EXECUTIVE SUMMARY}

A critical step in the Sludge Batch 4 (SB4) qualification process is to demonstrate the applicability of the durability models, which are used as part of the Defense Waste Processing Facility's (DWPF's) process control strategy, to the frit / SB4 glass system via a variability study. A variability study is an experimentally-driven assessment of the predictability and acceptability of the vitrified waste product quality that is anticipated from the processing of a sludge batch. The quality of the waste form is a measure of its durability as determined by the Product Consistency Test (PCT). At the DWPF, the durability of the vitrified waste product is not directly measured by this test during normal operation. Instead, the durability is predicted using a set of models that relate the PCT response of a glass to the chemical composition of that glass. The main objective of a variability study is to demonstrate that these models are applicable to the glass composition region anticipated during the processing of the sludge batch. The success of this demonstration allows the DWPF to confidently rely on the predictions of the durability/composition models as they are used in the control of the DWPF process.

The glass region for the SB4 variability study was determined using the most recent projections of the compositions of this sludge batch. Variation was introduced into the composition of the sludge to account for the uncertainty present in these projections as well as for process variation that may be experienced at the DWPF during its normal operations. The primary focus will be on the use of Frit 503, as this frit was recommended for SB4 processing. However, the frit recommendation memorandum also stated that Frit 418 is a viable option, especially for DWPF processing during the transition from SB3 to SB4 (i.e., an acceptable product can be produced with both SB3 and SB4 when Frit 418 is used). ${ }^{\text {a }}$ As a result, there is interest in selecting some glasses from the SB4 / Frit 418 system.

In this report, glasses are selected for the variability study using a nominal SB4 composition combined with Frits 418 or 503, covering a range of waste loadings (WLs) that are likely to be processed at DWPF. In addition, three sets of corner points or extreme vertices (EVs) for regions representing different levels of variation in the SB4 composition are combined with Frit 503 to identify glasses that will allow for an evaluation of the effect of sludge variation on the durability of the vitrified waste product. These glasses also cover a range of WLs that are likely to be processed at DWPF. A thorough statistical analysis is used to allow for a wide range of sludge compositions to be examined while minimizing the number of glasses that must be made in the laboratory. A total of 35 glasses are selected for the SB4 variability study.

These glasses will be batched and melted following standard SRNL procedures, and testing will be completed to measure the chemical durability of each glass composition. A subsequent report will document the results of the experimental portion of the SB4 variability study.

Frit 503 was recommended for the majority of SB4 processing since this higher $\mathrm{B}_{2} \mathrm{O}_{3}$-containing frit has advantages over Frit 418 in melt rate and is less prone to nepheline crystallization. ${ }^{1}$ 


\section{TABLE OF CONTENTS}

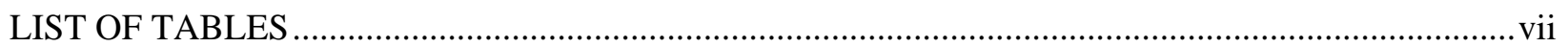

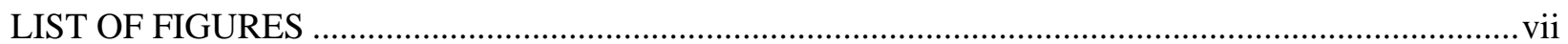

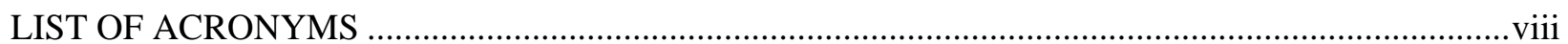

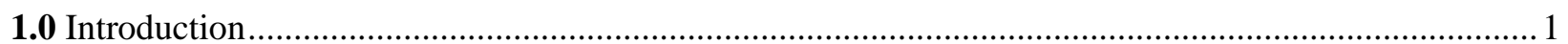

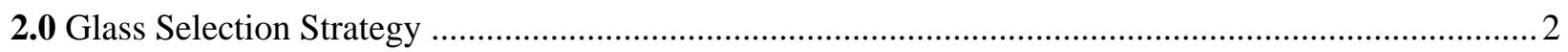

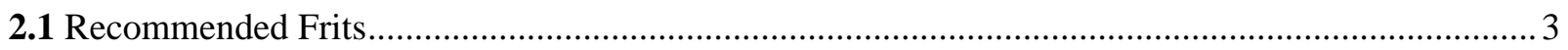

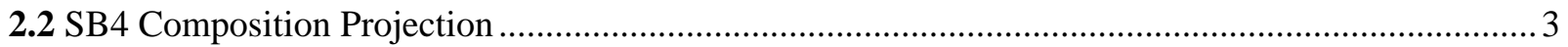

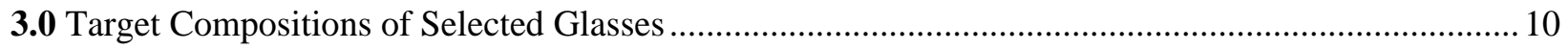

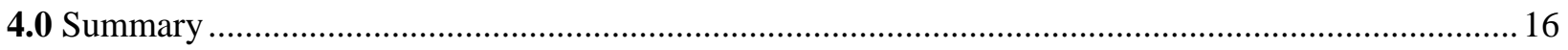

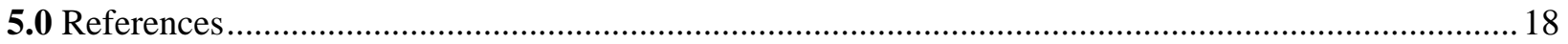




\section{LIST OF TABLES}

Table 2-1. Composition of the frits recommended for SB4 processing (in wt\%)..................................... 3

Table 2-2. Nominal SB4 composition projections and sludge composition space with traditional EVs

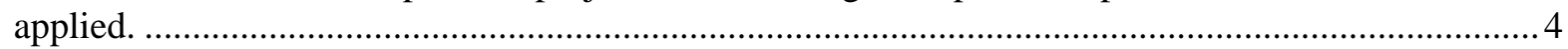

Table 2-3. Minor oxides making up the composition of Others (in wt\%). ............................................. 4

Table 2-4. Three compositional layers for SB4. ….............................................................................. 5

Table 3-1. Target glass compositions for Frit 418 with the centroid SB4 composition (in wt\%). ............11

Table 3-2. Target glass compositions for Frit 503 with the centroid SB4 composition (in wt\%).............12

Table 3-3. Target glass compositions for Frit 503 with the inner layer SB4 EVs (in wt\%).....................13

Table 3-4. Target glass compositions for Frit 503 with the outer layer SB4 EVs (in wt\%)..................... 14

Table 3-5. Target glass compositions with Frit 503 and the outermost layer SB4 EVs (in wt\%)............ 15

\section{LIST OF FIGURES}

Figure 2-1. Assessment of PCCS MAR criteria for SB4 / Frit 418 glasses. ........................................... 7

Figure 2-2. Assessment of PCCS MAR criteria for SB4 / Frit 503 glasses........................................... 7

Figure 2-3. Overview of the SB4 variability study glass selection strategy. ........................................... 9 


\section{LIST OF ACRONYMS}

$\begin{array}{ll}\text { DWPF } & \text { Defense Waste Processing Facility } \\ \text { EVs } & \text { Extreme Vertices } \\ \text { HLW } & \text { High Level Waste } \\ \text { MAR } & \text { Measurement Acceptability Region } \\ \text { PCCS } & \text { Product Composition Control System } \\ \text { PCT } & \text { Product Consistency Test } \\ \text { SB3 / SB4 } & \text { Sludge Batch 3 / Sludge Batch 4 } \\ \text { SRNL } & \text { Savannah River National Laboratory } \\ \text { WL } & \text { Waste Loading (weight percent) }\end{array}$


WSRC-STI-2006-00039

Revision 0

\subsection{Introduction}

The Defense Waste Processing Facility (DWPF) is preparing for vitrification of Sludge Batch 4 (SB4) in early FY2007. To support this process, the Savannah River National Laboratory (SRNL) has provided recommendations for the frit composition to be used in vitrifying this sludge batch. ${ }^{1}$ These recommendations were based on the most current composition projections for SB4, ${ }^{\mathrm{a}}$ assessments of operating windows in waste loading (WL) space, ${ }^{2-7}$ melt rate data, ${ }^{8}$ the potential for nepheline formation (a crystalline phase that is detrimental to product performance) and the chemical durability of test glasses. ${ }^{9-16}$

A critical step in the Sludge Batch 4 (SB4) qualification process is to demonstrate the applicability of the durability models, ${ }^{17}$ which are used as part of the Defense Waste Processing Facility's (DWPF's) process control strategy, to the frit / SB4 glass system via a variability study. A variability study is an experimentally-driven assessment of the predictability and acceptability of the vitrified waste product quality that is anticipated from the processing of a sludge batch. The quality of the waste form is a measure of its durability as determined by the Product Consistency Test (PCT). At the DWPF, the durability of the vitrified waste product is not directly measured by this test during normal operation. Instead, the durability is predicted using a set of models that relate the PCT response of a glass to the chemical composition of that glass. The main objective of a variability study is to demonstrate that these models are applicable to the glass composition region anticipated during the processing of the sludge batch. The success of this demonstration allows the DWPF to confidently rely on the predictions of the durability/composition models as they are used in the control of the DWPF process.

The glass region for the SB4 variability study was determined using the same recent projections of the compositions of this sludge batch that led to SRNL's frit recommendation memorandum. ${ }^{1}$ Variation was introduced into the composition of the sludge to account for the uncertainty present in these predictions as well as for process variation that may be experienced at the DWPF during its normal operations. The primary focus will be on the use of Frit 503, as this frit was recommended for SB4 processing. ${ }^{1}$ However, the recommendation memorandum also stated that Frit 418 is a viable option for DWPF processing, especially during the transition from SB3 to SB4 (i.e., an acceptable product can be produced with both SB3 and SB4 when Frit 418 is used). ${ }^{\text {b }}$ As a result, there is interest in selecting some glasses from the SB4 / Frit 418 system.

In this report, glasses are selected for the variability study using a nominal SB4 composition combined with Frits 418 or 503, covering a range of waste loadings (WLs) that are likely to be processed at DWPF. In addition, three sets of corner points or extreme vertices (EVs) for regions representing different levels of variation in the SB4 composition are combined with Frit 503 to identify glasses that will allow for an evaluation of the effect of sludge variation on the durability of the vitrified waste product. These glasses also cover a range of WLs that are likely to be processed at DWPF. A thorough statistical analysis is used to allow for a wide range of sludge compositions to be examined while minimizing the number of glasses that must be made in the laboratory. A total of 35 glasses are selected for the SB4 variability study.

This work was initiated by a DWPF Technical Task Request ${ }^{18}$ and is performed under a SRNL Technical Task and Quality Assurance Plan. ${ }^{19}$

\footnotetext{
aPersonal communication with H. B. Shah, via email, on June 22, 2006 (see WSRC-NB-2006-00017 for details).

$\mathrm{b}$ Frit 503 was recommended for the majority of SB4 processing since this higher $\mathrm{B}_{2} \mathrm{O}_{3}$-containing frit has advantages over Frit 418 in melt rate and is less prone to nepheline crystallization. ${ }^{1}$
} 
WSRC-STI-2006-00039

Revision 0

This page intentionally left blank. 
WSRC-STI-2006-00039

Revision 0

\subsection{Glass Selection Strategy}

This section provides an overview of the glass selection strategy. A description of the two frits used in developing the glass composition range from which the variability study glasses are selected is presented. The development of the SB4 composition region covered by the variability study is outlined, and three expanding layers of variation are introduced to capture the likely compositional variation of this sludge.

\subsection{Recommended Frits}

The two frits described in SRNL's frit recommendation for SB4 processing ${ }^{1}$ will be utilized in this variability study. Frit 418 is currently used for processing of SB3 in the DWPF. Although SRNL does not believe that Frit 418 is the optimal frit, it could be used for processing of SB4. In particular, the frit selection memorandum stated that this frit is viable for use during the transition from SB3 to SB4, should DWPF choose to exhaust its remaining stock of this frit during the changeover period. Use of this frit during transition from SB3 to SB4 also minimizes any heel impacts from the blend of SB3 / Frit 418. Frit 503 was recommended for SB4 processing due to advantages over Frit 418 in melt rate and suppression of nepheline crystallization to higher WLs. The nominal compositions of these frits are listed in Table 2-1.

Table 2-1. Composition of the frits recommended for SB4 processing (in wt \%).

\begin{tabular}{|c|c|c|c|c|}
\hline \hline Frit ID & $\mathbf{B}_{2} \mathbf{O}_{3}$ & $\mathbf{L i}_{2} \mathbf{O}$ & $\mathbf{N a}_{\mathbf{2}} \mathbf{O}$ & $\mathbf{S i O}_{\mathbf{2}}$ \\
\hline 418 & 8 & 8 & 8 & 76 \\
\hline 503 & 14 & 8 & 4 & 74 \\
\hline
\end{tabular}

\subsection{SB4 Composition Projection}

Two nominal composition projections have been recently provided for SB4, Blend 1 (i.e., SB4 after transferring to a 113" heel of SB3). ${ }^{\text {a }}$ The first was referred to as the $0.92 \mathrm{M} \mathrm{Na}^{+}$with $12.2 \mathrm{wt} \%$ solids option. The second was referred to as the $0.912 \mathrm{M} \mathrm{Na}^{+}$with $12.6 \mathrm{wt} \%$ solids option. These projections were combined with the candidate frits as part of Nominal and Variation Stage assessments by the frit development team. ${ }^{20}$ Table 2-2 provides the nominal compositions for these two projections as well as the variation that was applied to each oxide as part of the Variation Stage assessment. Note that the variation applied to three of the oxides, $\mathrm{Al}_{2} \mathrm{O}_{3}, \mathrm{Fe}_{2} \mathrm{O}_{3}$ and $\mathrm{Na}_{2} \mathrm{O}$ is given as a percentage, while the variation applied to the other oxides is given in weight percent. The resulting concentration intervals for the major oxides (those oxides present in the sludge that will result in concentrations greater than $0.5 \mathrm{wt} \%$ in the glass) are also given in this table. The minor oxide components in the sludge were grouped into an "Others" category. The relative contribution of the minor oxide components to the "Others" grouping is the same for the two projections, as indicated in Table 2-3. The variation for "Others" was applied to the group as a whole.

\footnotetext{
a Personal communication with H. B. Shah, via email, on June 22, 2006 (see WSRC-NB-2006-00017 for details).
} 
Table 2-2. Nominal SB4 composition projections and sludge composition space with traditional EVs applied.

\begin{tabular}{|c|c|c|c|c|c|c|c|}
\hline \multirow[t]{2}{*}{$\begin{array}{c}\text { Oxide } \\
\text { Component }\end{array}$} & \multirow[t]{2}{*}{$\begin{array}{c}\text { Variation } \\
\text { (Traditional EVs) }\end{array}$} & \multirow[t]{2}{*}{$\begin{array}{c}\text { SB4 Blend-1 } \\
12.2 \text { wt } \% \text { solids }^{+} \\
0.92 \mathrm{M} \mathrm{Na}^{+} \\
\text {nominal composition } \\
\text { (wt } \%)\end{array}$} & \multirow{2}{*}{$\begin{array}{c}\text { SB4 Blend-1 } \\
12.6 \text { wt } \% \text { solids } \\
0.912 \mathrm{M} \mathrm{Na}^{+} \\
\text {nominal composition } \\
\text { (wt\%) } \\
\end{array}$} & \multicolumn{2}{|c|}{$\begin{array}{c}\text { SB4 Blend-1 } \\
12.2 \mathrm{wt} \% \text { solids } \\
0.92 \mathrm{M} \mathrm{Na}^{+} \\
\text {with variation applied }\end{array}$} & \multicolumn{2}{|c|}{$\begin{array}{c}\text { SB4 Blend-1 } \\
12.6 \mathrm{wt}^{\circ} \% \text { solids } \\
0.912 \mathrm{M} \mathrm{Na}^{+} \\
\text {with variation applied }\end{array}$} \\
\hline & & & & $\min (w t \%)$ & $\max (w t \%)$ & $\min (w t \%)$ & $\max (w t \%)$ \\
\hline $\mathrm{Al}_{2} \mathrm{O}_{3}$ & $7.5 \%$ & 23.617 & 23.831 & 21.969 & 25.532 & 22.168 & 25.762 \\
\hline $\mathrm{CaO}$ & $0.25 \mathrm{wt} \%$ & 2.350 & 2.371 & 2.100 & 2.600 & 2.121 & 2.621 \\
\hline $\mathrm{Fe}_{2} \mathrm{O}_{3}$ & $7.5 \%$ & 26.017 & 26.253 & 24.202 & 28.127 & 24.421 & 28.381 \\
\hline $\mathrm{MgO}$ & $0.25 \mathrm{wt} \%$ & 2.480 & 2.502 & 2.230 & 2.730 & 2.252 & 2.752 \\
\hline $\mathrm{MnO}$ & $0.25 \mathrm{wt} \%$ & 5.394 & 5.442 & 5.144 & 5.644 & 5.192 & 5.692 \\
\hline $\mathrm{Na}_{2} \mathrm{O}$ & $7.5 \%$ & 23.753 & 23.131 & 22.096 & 25.679 & 21.517 & 25.006 \\
\hline $\mathrm{NiO}$ & $0.25 \mathrm{wt} \%$ & 1.545 & 1.559 & 1.295 & 1.795 & 1.309 & 1.809 \\
\hline $\mathrm{SO}_{4}{ }^{2-}$ & $0.1 \mathrm{wt} \%$ & 1.417 & 1.368 & 1.317 & 1.517 & 1.268 & 1.468 \\
\hline $\mathrm{SiO}_{2}$ & $0.25 \mathrm{wt} \%$ & 3.963 & 3.998 & 3.713 & 4.213 & 3.748 & 4.248 \\
\hline $\mathrm{U}_{3} \mathrm{O}_{8}$ & $0.25 \mathrm{wt} \%$ & 7.563 & 7.632 & 7.313 & 7.813 & 7.382 & 7.882 \\
\hline Others & $0.25 \mathrm{wt} \%$ & 1.486 & 1.500 & 1.236 & 1.736 & 1.250 & 1.750 \\
\hline
\end{tabular}

Table 2-3. Minor oxides making up the composition of Others (in wt\%).

\begin{tabular}{|c|c|c|c|c|c|c|c|c|c|c|c|c|}
\hline Option & $\mathbf{B a O}$ & $\mathbf{C e}_{2} \mathbf{O}_{3}$ & $\mathbf{C r}_{\mathbf{2}} \mathbf{O}_{3}$ & $\mathbf{C u O}$ & $\mathbf{K}_{\mathbf{2}} \mathbf{O}$ & $\mathbf{L a}_{2} \mathbf{O}_{3}$ & $\mathbf{P b O}$ & $\mathbf{T h O}_{2}$ & $\mathbf{T i O}_{2}$ & $\mathbf{Z n O}$ & $\mathbf{Z r O}$ & $\mathbf{O t h e r s}$ \\
\hline $\begin{array}{c}\text { SB4 Blend-1, } \\
\text { 12.2 wt\% solids, } \\
0.92 \mathrm{M} \mathrm{Na}{ }^{+}\end{array}$ & 8.335 & 10.088 & 13.975 & 4.028 & 22.153 & 7.123 & 6.099 & 4.220 & 1.757 & 6.576 & 15.645 & 100.000 \\
\hline $\begin{array}{c}\text { SB4 Blend-1, } \\
12.6 \text { wt\% solids, } \\
0.912 \mathrm{M} \mathrm{Na}^{+}\end{array}$ & 8.335 & 10.088 & 13.975 & 4.028 & 22.153 & 7.123 & 6.099 & 4.220 & 1.757 & 6.576 & 15.645 & 100.000 \\
\hline
\end{tabular}


As seen in Tables 2-2 and 2-3, the two nominal SB4 composition projections are very similar with the biggest difference being in their $\mathrm{Na}_{2} \mathrm{O}$ concentrations. This translates into very similar concentration intervals being used as input to the respective variation stage assessments. These similarities led to a decision to combine the two compositional views into a single sludge compositional region for the SB4 variability study. This was accomplished as follows: The smaller of the two minimum values and the larger of the two maximum values for each oxide component of the two SB4 composition projections with variation applied (the right side of Table 2-2) were used to define the outer layer of the sludge composition space for the SB4 variability study. The results of this selection are shown in Table 2-4. Two other layers, one interior to the outer layer and one more bounding than the outer layer, were defined in sludge composition space to better capture the potential variation of the SB4 composition. An inner layer concentration interval for each sludge component was determined by moving each of the endpoints of the outer layer interval in by $25 \%$ of the width of the outer layer interval for that component. An outermost layer was determined by rounding off the endpoints of the outer layer interval for each component. The maximum weight percent values of the outer layer interval were rounded up to the nearest whole number and the minimum weight percent values were rounded down to the nearest whole number. The outermost layer was introduced to accommodate possible changes in the SB4 composition projection before processing begins at DWPF. The three SB4 compositional layers defined by this methodology are given in Table 2-4.

Table 2-4. Three compositional layers for SB4.

\begin{tabular}{|c|c|c|c|c|c|c|}
\hline \multirow{2}{*}{$\begin{array}{c}\text { Oxide } \\
\text { Component }\end{array}$} & \multicolumn{2}{|c|}{ Inner Layer } & \multicolumn{2}{|c|}{ Outer Layer } & \multicolumn{2}{|c|}{ Outermost Layer } \\
\hline & $\min (w t \%)$ & $\max (w t \%)$ & $\min (w t \%)$ & $\max (w t \%)$ & $\min (w t \%)$ & $\max (w t \%)$ \\
\hline $\mathrm{Al}_{2} \mathrm{O}_{3}$ & 22.917 & 24.814 & 21.969 & 25.762 & 21 & 26 \\
\hline $\mathrm{CaO}$ & 2.230 & 2.491 & 2.100 & 2.621 & 2 & 3 \\
\hline $\mathrm{Fe}_{2} \mathrm{O}_{3}$ & 25.247 & 27.336 & 24.202 & 28.381 & 24 & 29 \\
\hline $\mathrm{MgO}$ & 2.361 & 2.622 & 2.230 & 2.752 & 2 & 3 \\
\hline $\mathrm{MnO}$ & 5.281 & 5.555 & 5.144 & 5.692 & 5 & 6 \\
\hline $\mathrm{Na}_{2} \mathrm{O}$ & 22.558 & 24.639 & 21.517 & 25.679 & 21 & 26 \\
\hline $\mathrm{NiO}$ & 1.424 & 1.681 & 1.295 & 1.809 & 1 & 2 \\
\hline $\mathrm{SO}_{4}{ }^{2-}$ & 1.330 & 1.455 & 1.268 & 1.517 & 1 & 2 \\
\hline $\mathrm{SiO}_{2}$ & 3.847 & 4.114 & 3.713 & 4.248 & 3 & 5 \\
\hline $\mathrm{U}_{3} \mathrm{O}_{8}$ & 7.455 & 7.740 & 7.313 & 7.882 & 7 & 8 \\
\hline Others & 1.365 & 1.622 & 1.236 & 1.750 & 1 & 2 \\
\hline
\end{tabular}

The information in Table 2-4 provided the framework for generating sludge compositions used to represent SB4. For example, consider the inner layer described in Table 2-4. A sludge composition is in the region defined by this layer if its concentration of each oxide is within the min and max interval for that oxide (e.g., the $\mathrm{Al}_{2} \mathrm{O}_{3}$ concentration in the sludge is between 22.917 and $24.814 \mathrm{wt} \%$ ) and the sum of the concentrations of all of the oxides in the sludge is $100 \mathrm{wt} \%$. Such a composition would be a mixture of oxides at concentrations that correspond to one of the possible compositions for that sludge option as defined by the inner layer in Table 2-4. Algorithms are available in statistical software packages such as $\mathrm{JMP}^{21}$ to generate the compositions that are the "corner points" of the bounding region defined by a layer of Table 2-4. 
The bounding “corner-point” compositions generated by JMP are called the EVs of the region defined by the min and max intervals of the sludge layer.

JMP software ${ }^{21}$ was used to generate the EVs of the sludge regions defined by the information in Table 2-4. For the "Others" component, the concentration for an EV was generated by JMP. This concentration was then exploded into the oxides comprising "Others" using the percentages of Table 2-3. A centroid was determined for the SB4 composition region by averaging the EVs of the inner layer.

With these sludge compositions in hand (i.e., the centroid and the EVs for the inner layer, the EVs for outer layer, and the EVs for the outermost layer), glass compositions were determined by combining the centroid and each of the EVs with Frit 418 and with Frit 503 at WLs from 25 to $60 \%$ in increments of 1 percentage point. The resulting glass compositions were assessed using the Measurement Acceptability Region (MAR) criteria of DWPF's Product Composition Control System (PCCS). The results are summarized in Figure 2-1 for Frit 418 and in Figure 2-2 for Frit 503. These figures reveal projected operating intervals (i.e., the range of WLs over which all PCCS MAR criteria are met) for the centroid SB4 composition of 25 to 44\% for Frit 418 and 25 to $46 \%$ for Frit 503 . At $45 \%$ WL, the Frit 418 centroid-based system becomes nepheline limited (consistent with previous observations). At 47\% WL, the Frit 503 centroid based system becomes both $\mathrm{T}_{\mathrm{L}}$ and nepheline limited. Note however that these projected operating intervals do not account for $\mathrm{SO}_{4}{ }^{2-}$ limits.

Some of the EVs yield MAR-acceptable glasses at WLs at or above $45 \%$ for both the Frit 418 and the Frit 503 glass systems. For an interpretation of the EV-based assessment, consider the Frit 503 / inner layer EV results shown in Figure 2-2. All of the inner layer EVs meet the PCCS MAR criteria up to $42 \%$ WL. At $43 \%$ WL, some of the EVs meet the PCCS MAR criteria while some of the EVs are $T_{L}$ limited. It is not until $46 \% \mathrm{WL}$ that some of the inner layer EVs fail the nepheline MAR criterion. Again, one of the attributes of the Frit 503 system is suppression of nepheline formation concerns to higher WLs. None of the inner layer EVs meet the PCCS MAR criteria above $47 \%$ WL. The glasses that meet all of the PCCS MAR criteria are candidates for inclusion in the SB4 variability study.

Note that no glasses will be selected from the Frit 418 EV based assessment. A limited number of Frit 418 glasses will be selected using the centroid composition only. Therefore, the information shown in Figure 2-1 has limited use in terms of the glass selection process, but may become valuable information if Frit 418 is used to process SB4 (for reasons other than the transition period). 


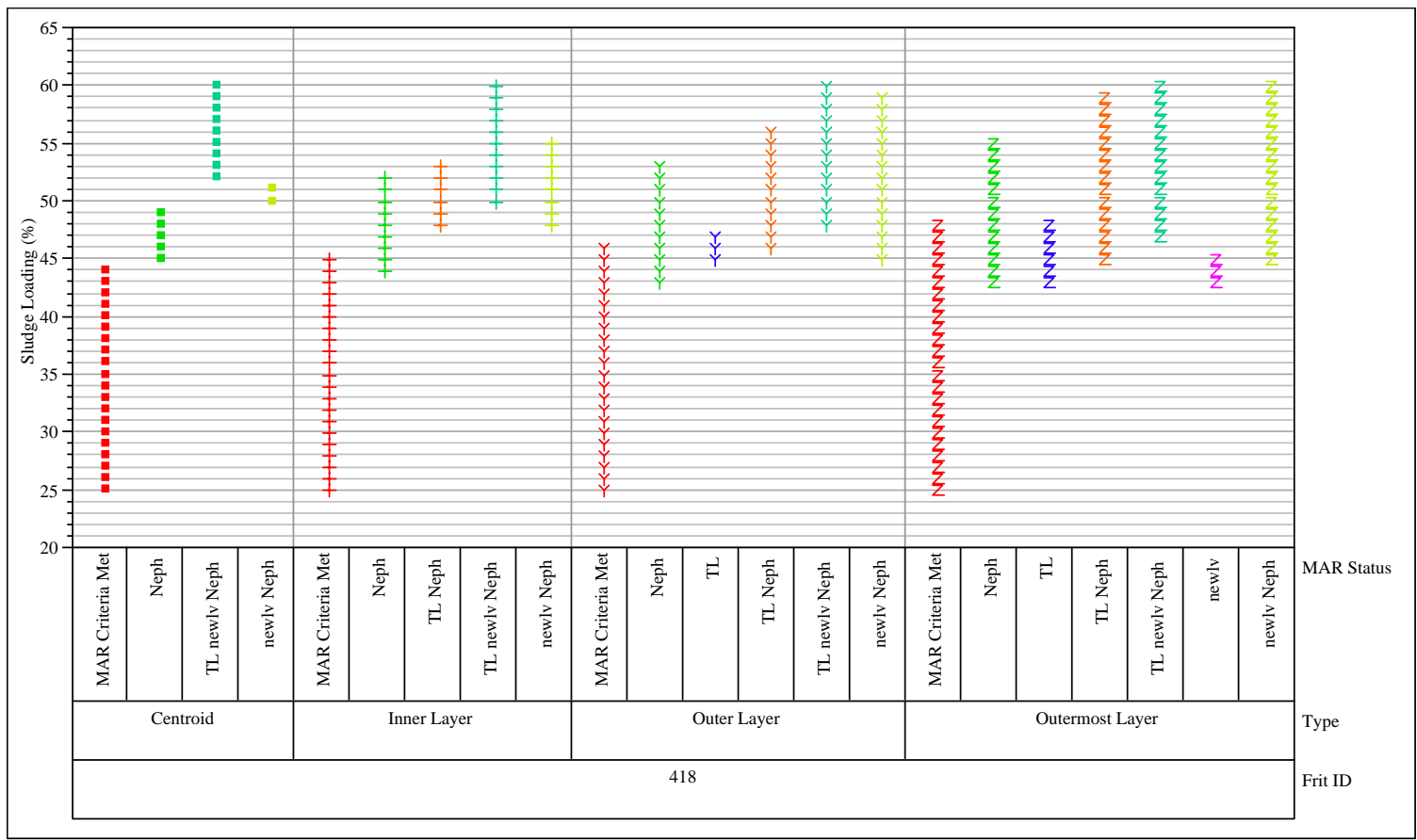

Figure 2-1. Assessment of PCCS MAR criteria for SB4 / Frit 418 glasses.

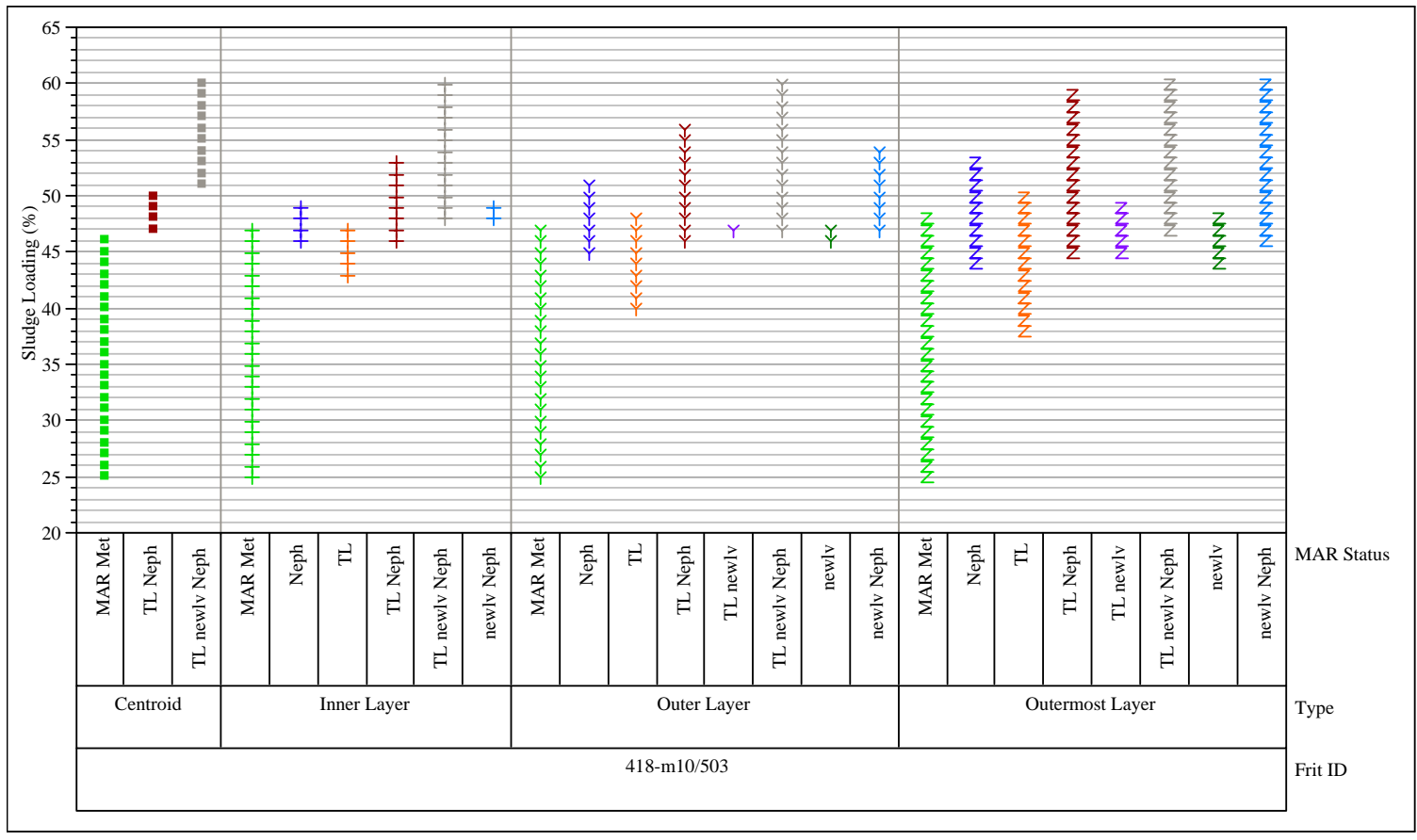

Figure 2-2. Assessment of PCCS MAR criteria for SB4 / Frit 503 glasses. 
A graphical overview of the process that was used to select the glasses for the variability study is presented in Figure 2-3. First, four glasses were selected using the SB4 centroid composition and Frit 418. Four WLs from 32-44 wt\% were selected as this range is likely to be used during the transition from SB3 to SB4 processing at the DWPF (if Frit 418 is utilized during the transition). These are the only Frit 418 glasses that were selected, since it is anticipated that Frit 418 will only be used during the transition from SB3 to SB4. Next, five glasses were selected using the SB4 centroid composition and Frit 503, covering a range of WLs from 30-46 wt\%.

To support the selection of glasses from the Frit 503, inner most layer, the D-optimization routine, available in JMP Version 3.2.6, ${ }^{22}$ was used to select 12 individual compositions from the set of inner layer EVs. These 12 data points were D-optimal ${ }^{\text {a }}$ relative to a linear mixture model in the 11 components of Table 2-2. A set of 10 additional data points was selected from the outer layer EVs using the D-optimization routine to complement the first set of 12 data points. Finally, 4 more data points were optimally added from the outermost layer EVs. This process led to the selection of 27 sludge compositions over the three sludge layers which were combined with Frit 503 at WLs as indicated in Figure 2-3 (e.g., for the outermost layer EVs, WLs of 34, 36, 38, and $40 \%$ were used) to determine glass compositions. Note that all of the WLs selected meet the MAR criteria as shown in Figures 2-1 and 2-2. The numbers of glasses from each layer and at each WL indicated in the lower portion of the figure were selected for the variability study. A total of 35 glasses were selected using this strategy.

It should be noted that prior to finalizing the 35 glass test matrix, a search was performed using JMP to determine if any glasses within the ComPro and Nepheline glass composition/properties databases $^{23,24}$ could be used to support the SB4 variability study. The variability study glasses selected using Frit 418 all fall in a compositional region that is outside the range covered by SRNL's existing databases. The compositions of some of the Frit 503 variability study glasses fall close to those of the five glasses studied in a recently issued Frit 503 study. ${ }^{12}$ One of the glasses in that study was found to be unpredictable using the PCCS models, but had an acceptable durability and did not show nepheline crystallization at a detectible level. ${ }^{12}$ These results suggest that further exploration is needed in this compositional region to demonstrate that the durability models are applicable to the Frit 503 / SB4 system. Therefore, all of the Frit 503 glasses described above will be fabricated for the variability study.

\footnotetext{
${ }^{a}$ See the Statistics and Graphics Guide for the JMP Version 3.2.6 software for a discussion of optimality criteria (including D-optimality) available for selecting a test matrix from a candidate set of design points to support the fitting of a proposed statistical model. ${ }^{22}$
} 


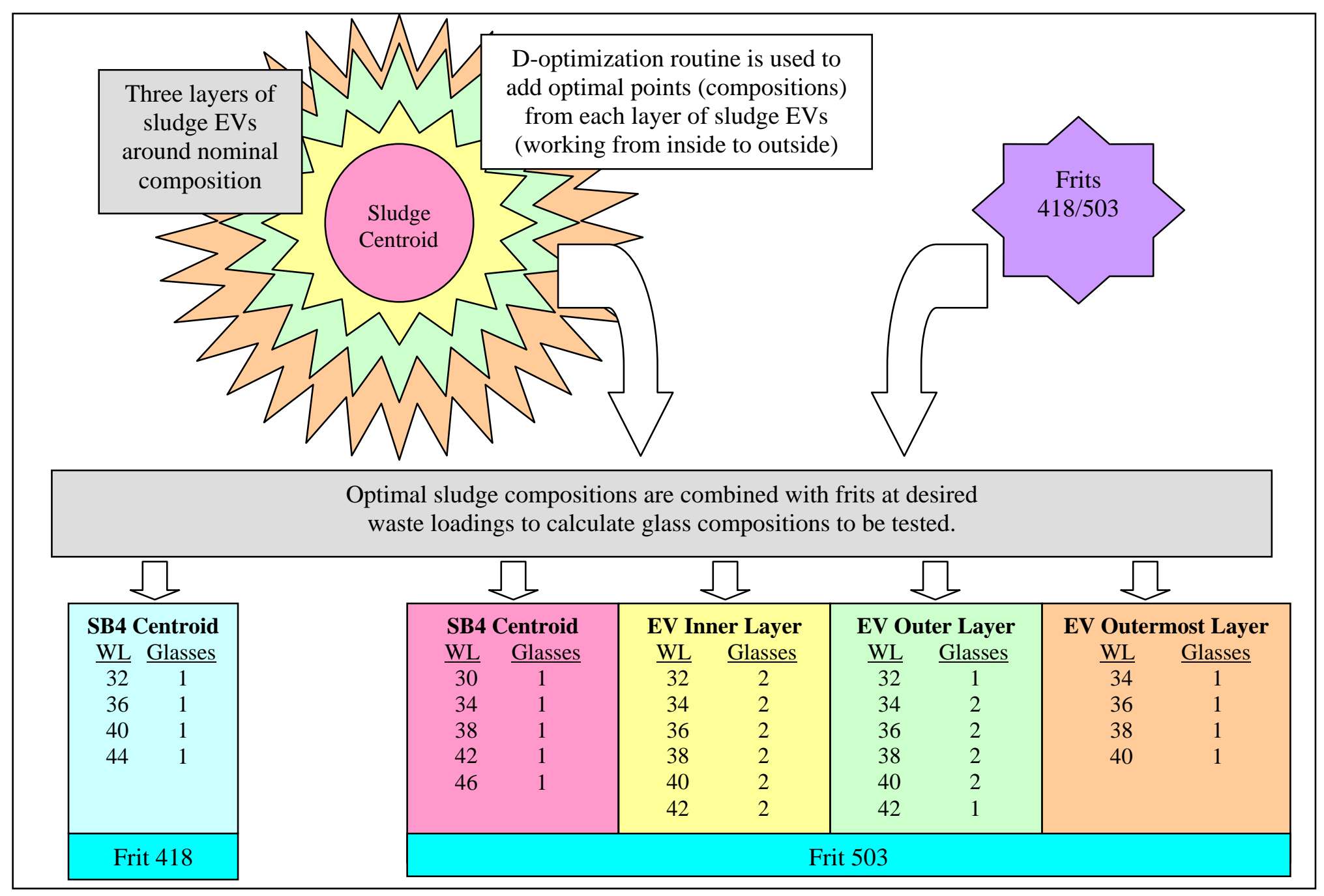

Figure 2-3. Overview of the SB4 variability study glass selection strategy. 
WSRC-STI-2006-00039

Revision 0

This page intentionally left blank. 


\subsection{Target Compositions of Selected Glasses}

The target compositions of the SB4 variability study glasses are presented in this section. As previously noted, all of these compositions satisfy the PCCS MAR criteria. The glasses have been grouped by frit, and sub-grouped by EV layer. Compositions of the glasses composed of Frit 418 and the centroid SB4 composition are given in Table 3-1. Here the "Others" category has been separated into individual oxide components. The glasses composed of Frit 503 and the centroid SB4 composition are listed in Table 3-2. The glasses composed of each of the three SB4 EV layers (inner, outer and outermost) combined with Frit 503 are listed in Tables 3-3, 3-4 and $3-5$, respectively. Note that some of the selected glass compositions have $\mathrm{SO}_{4}{ }^{2-}$ concentrations in excess of the $0.60 \mathrm{wt} \%$ limit established previously for SB3 / Frit 418 processing. ${ }^{25}$ This is not seen as a threat to the success of the variability study, but could provide valuable feedback into the $\mathrm{SO}_{4}{ }^{2-}$ retention issue given that uncertainty exists in the projected $\mathrm{SO}_{4}{ }^{2-}$ concentration in SB4. A parallel study is underway using SB4 glasses with artificially high $\mathrm{SO}_{4}{ }^{2-}$ concentrations to determine whether the sulfate limit can be raised for SB4 processing. ${ }^{26}$

Table 3-1. Target glass compositions for Frit 418 with the centroid SB4 composition (in wt\%).

\begin{tabular}{||c|c|c|c|c||}
\hline Glass ID & SB4VS-01 & SB4VS-02 & SB4VS-03 & SB4VS-04 \\
\hline $\mathbf{W L}$ & $\mathbf{3 2}$ & $\mathbf{3 6}$ & $\mathbf{4 0}$ & $\mathbf{4 4}$ \\
\hline $\mathrm{Al}_{2} \mathrm{O}_{3}$ & 7.631 & 8.585 & 9.539 & 10.493 \\
\hline $\mathrm{B}_{2} \mathrm{O}_{3}$ & 5.440 & 5.120 & 4.800 & 4.480 \\
\hline $\mathrm{BaO}$ & 0.040 & 0.045 & 0.050 & 0.055 \\
\hline $\mathrm{CaO}$ & 0.756 & 0.850 & 0.944 & 1.039 \\
\hline $\mathrm{Ce}_{2} \mathrm{O}_{3}$ & 0.048 & 0.054 & 0.060 & 0.066 \\
\hline $\mathrm{Cr}_{2} \mathrm{O}_{3}$ & 0.067 & 0.075 & 0.084 & 0.092 \\
\hline $\mathrm{CuO}_{\mathrm{Fe}_{2} \mathrm{O}_{3}}$ & 0.019 & 0.022 & 0.024 & 0.026 \\
\hline $\mathrm{K}_{2} \mathrm{O}$ & 0.407 & 9.458 & 10.509 & 11.560 \\
\hline $\mathrm{La}_{2} \mathrm{O}_{3}$ & 0.034 & 0.038 & 0.043 & 0.047 \\
\hline $\mathrm{Li}_{2} \mathrm{O}$ & 5.440 & 5.120 & 4.800 & 4.480 \\
\hline $\mathrm{MgO}_{\mathrm{MnO}}$ & 0.797 & 0.897 & 0.997 & 1.096 \\
\hline $\mathrm{Mn}_{2} \mathrm{O}$ & 1.734 & 1.951 & 2.167 & 2.384 \\
\hline $\mathrm{NiO}^{2} \mathrm{O}$ & 0.499 & 13.612 & 14.236 & 14.859 \\
\hline $\mathrm{PbO}^{2-}$ & 0.029 & 0.559 & 0.621 & 0.683 \\
\hline $\mathrm{SO}_{4}{ }^{2-}$ & 0.446 & 0.501 & 0.557 & 0.613 \\
\hline $\mathrm{SiO}_{2}$ & 52.954 & 50.073 & 47.192 & 44.312 \\
\hline $\mathrm{ThO}_{2}$ & 0.020 & 0.023 & 0.025 & 0.028 \\
\hline $\mathrm{TiO}_{2}$ & 0.008 & 0.009 & 0.011 & 0.012 \\
\hline $\mathrm{U}_{3} \mathrm{O}_{8}$ & 2.431 & 2.735 & 3.039 & 3.343 \\
\hline $\mathrm{ZnO}_{2 \mathrm{OrO}}$ & 0.031 & 0.035 & 0.039 & 0.043 \\
\hline & 0.075 & 0.084 & 0.094 & 0.103 \\
\hline \hline
\end{tabular}


Table 3-2. Target glass compositions for Frit 503 with the centroid SB4 composition (in wt \%).

\begin{tabular}{|c|c|c|c|c|c||}
\hline Glass ID & SB4VS-05 & SB4VS-06 & SB4VS-07 & SB4VS-08 & SB4VS-09 \\
\hline $\mathbf{W L}$ & $\mathbf{3 0}$ & $\mathbf{3 4}$ & $\mathbf{3 8}$ & $\mathbf{4 2}$ & $\mathbf{4 6}$ \\
\hline $\mathrm{Al}_{2} \mathrm{O}_{3}$ & 7.154 & 8.108 & 9.062 & 10.016 & 10.970 \\
\hline $\mathrm{B}_{2} \mathrm{O}_{3}$ & 9.800 & 9.240 & 8.680 & 8.120 & 7.560 \\
\hline $\mathrm{BaO}$ & 0.037 & 0.042 & 0.047 & 0.052 & 0.057 \\
\hline $\mathrm{CaO}$ & 0.708 & 0.803 & 0.897 & 0.992 & 1.086 \\
\hline $\mathrm{Ce}_{2} \mathrm{O}_{3}$ & 0.045 & 0.051 & 0.057 & 0.063 & 0.069 \\
\hline $\mathrm{Cr}_{2} \mathrm{O}_{3}$ & 0.063 & 0.071 & 0.079 & 0.088 & 0.096 \\
\hline $\mathrm{CuO}_{\mathrm{Fe}_{2} \mathrm{O}_{3}}$ & 0.018 & 0.021 & 0.023 & 0.025 & 0.028 \\
\hline $\mathrm{K}_{2} \mathrm{O}$ & 0.0982 & 8.933 & 9.984 & 11.035 & 12.086 \\
\hline $\mathrm{La}_{2} \mathrm{O}_{3}$ & 0.032 & 0.113 & 0.126 & 0.139 & 0.152 \\
\hline $\mathrm{Li}_{2} \mathrm{O}$ & 5.600 & 5.280 & 4.960 & 4.640 & 4.320 \\
\hline $\mathrm{MgO}^{\mathrm{MnO}}$ & 0.748 & 0.847 & 0.947 & 1.047 & 1.146 \\
\hline $\mathrm{Na}_{2} \mathrm{O}$ & 1.626 & 1.842 & 2.059 & 2.276 & 2.493 \\
\hline $\mathrm{NiO}$ & 0.877 & 10.660 & 11.444 & 12.228 & 13.011 \\
\hline $\mathrm{PbO}_{\mathrm{SO}}^{2-}$ & 0.466 & 0.528 & 0.590 & 0.652 & 0.714 \\
\hline $\mathrm{SiO}_{2}$ & 0.418 & 0.474 & 0.529 & 0.585 & 0.641 \\
\hline $\mathrm{ThO}_{2}$ & 0.019 & 0.021 & 0.024 & 0.027 & 0.029 \\
\hline $\mathrm{TiO}_{2}$ & 0.008 & 0.009 & 0.010 & 0.011 & 0.012 \\
\hline $\mathrm{U}_{3} \mathrm{O}_{8}$ & 2.279 & 2.583 & 2.887 & 3.191 & 3.495 \\
\hline $\mathrm{ZnO}_{\mathrm{ZrO}}$ & 0.030 & 0.033 & 0.037 & 0.041 & 0.045 \\
\hline & 0.070 & 0.080 & 0.089 & 0.098 & 0.108 \\
\hline
\end{tabular}


Table 3-3. Target glass compositions for Frit 503 with the inner layer SB4 EVs (in wt\%).

\begin{tabular}{|c|c|c|c|c|c|c|c|c|c|c|c|c|}
\hline Glass ID & 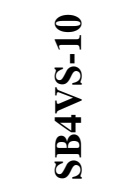 & 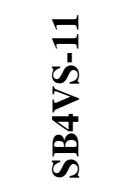 & $\underset{\infty}{\stackrel{1}{*}}$ & $\sum_{n}^{n}$ & $\underset{\sim}{ \pm}$ & 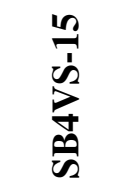 & 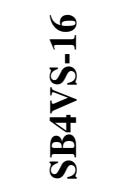 & $\underset{\sim}{\stackrel{D}{*}}$ & $\sum_{\infty}^{\infty}$ & $\underset{\infty}{\stackrel{0}{7}}$ & 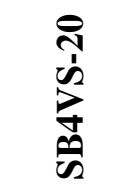 & 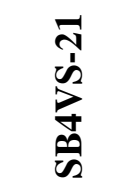 \\
\hline WL & 42 & 42 & 40 & 40 & 38 & 38 & 36 & 36 & 34 & 34 & 32 & 32 \\
\hline $\mathrm{Al}_{2} \mathrm{O}_{3}$ & 10.047 & 10.422 & 9.926 & 9.926 & 8.709 & 8.709 & 8.250 & 8.933 & 8.036 & 7.792 & 7.516 & 7.941 \\
\hline $\mathrm{B}_{2} \mathrm{O}_{3}$ & 8.120 & 8.120 & 8.400 & 8.400 & 8.680 & 8.680 & 8.960 & 8.960 & 9.240 & 9.240 & 9.520 & 9.520 \\
\hline $\mathrm{BaO}$ & 0.057 & 0.048 & 0.054 & 0.046 & 0.043 & 0.051 & 0.049 & 0.041 & 0.039 & 0.039 & 0.043 & 0.043 \\
\hline $\mathrm{CaO}$ & 1.046 & 0.937 & 0.892 & 0.996 & 0.947 & 0.847 & 0.803 & 0.803 & 0.847 & 0.758 & 0.797 & 0.797 \\
\hline $\mathrm{Ce}_{2} \mathrm{O}_{3}$ & 0.069 & 0.058 & 0.066 & 0.055 & 0.052 & 0.062 & 0.059 & 0.050 & 0.047 & 0.047 & 0.052 & 0.052 \\
\hline $\mathrm{Cr}_{2} \mathrm{O}_{3}$ & 0.095 & 0.080 & 0.091 & 0.076 & 0.073 & 0.086 & 0.082 & 0.069 & 0.065 & 0.065 & 0.073 & 0.073 \\
\hline $\mathrm{CuO}$ & 0.027 & 0.023 & 0.026 & 0.022 & 0.021 & 0.025 & 0.024 & 0.020 & 0.019 & 0.019 & 0.021 & 0.021 \\
\hline $\mathrm{Fe}_{2} \mathrm{O}_{3}$ & 10.604 & 10.604 & 10.408 & 10.611 & 10.013 & 10.388 & 9.588 & 9.700 & 9.294 & 8.825 & 8.748 & 8.079 \\
\hline $\mathrm{K}_{2} \mathrm{O}$ & 0.151 & 0.127 & 0.144 & 0.121 & 0.115 & 0.137 & 0.129 & 0.109 & 0.103 & 0.103 & 0.115 & 0.115 \\
\hline $\mathrm{La}_{2} \mathrm{O}_{3}$ & 0.049 & 0.041 & 0.046 & 0.039 & 0.037 & 0.044 & 0.042 & 0.035 & 0.033 & 0.033 & 0.037 & 0.037 \\
\hline $\mathrm{Li}_{2} \mathrm{O}$ & 4.640 & 4.640 & 4.800 & 4.800 & 4.960 & 4.960 & 5.120 & 5.120 & 5.280 & 5.280 & 5.440 & 5.440 \\
\hline $\mathrm{MgO}$ & 0.992 & 0.992 & 1.049 & 1.049 & 0.897 & 0.897 & 0.944 & 0.850 & 0.892 & 0.892 & 0.756 & 0.839 \\
\hline $\mathrm{MnO}$ & 2.218 & 2.333 & 2.222 & 2.112 & 2.111 & 2.111 & 1.901 & 1.901 & 1.889 & 1.796 & 1.690 & 1.778 \\
\hline $\mathrm{Na}_{2} \mathrm{O}$ & 12.668 & 12.329 & 11.423 & 11.423 & 11.843 & 11.415 & 11.430 & 10.681 & 10.310 & 11.017 & 9.939 & 10.053 \\
\hline $\mathrm{NiO}$ & 0.706 & 0.706 & 0.672 & 0.570 & 0.541 & 0.541 & 0.513 & 0.513 & 0.572 & 0.572 & 0.538 & 0.456 \\
\hline $\mathrm{PbO}$ & 0.042 & 0.035 & 0.040 & 0.033 & 0.032 & 0.038 & 0.036 & 0.030 & 0.028 & 0.028 & 0.032 & 0.032 \\
\hline $\mathrm{SO}_{4}{ }^{2-}$ & 0.611 & 0.559 & 0.532 & 0.532 & 0.505 & 0.553 & 0.479 & 0.524 & 0.495 & 0.495 & 0.426 & 0.466 \\
\hline $\mathrm{SiO}_{2}$ & 44.536 & 44.536 & 46.046 & 45.939 & 47.443 & 47.342 & 48.745 & 48.841 & 50.148 & 50.239 & 51.637 & 51.637 \\
\hline $\mathrm{ThO}_{2}$ & 0.029 & 0.024 & 0.027 & 0.023 & 0.022 & 0.026 & 0.025 & 0.021 & 0.020 & 0.020 & 0.022 & 0.022 \\
\hline $\mathrm{TiO}_{2}$ & 0.012 & 0.010 & 0.011 & 0.010 & 0.009 & 0.011 & 0.010 & 0.009 & 0.008 & 0.008 & 0.009 & 0.009 \\
\hline $\mathrm{U}_{3} \mathrm{O}_{8}$ & 3.131 & 3.251 & 2.982 & 3.096 & 2.833 & 2.941 & 2.684 & 2.684 & 2.535 & 2.632 & 2.477 & 2.477 \\
\hline $\mathrm{ZnO}$ & 0.045 & 0.038 & 0.043 & 0.036 & 0.034 & 0.041 & 0.038 & 0.032 & 0.031 & 0.031 & 0.034 & 0.034 \\
\hline $\mathrm{ZrO}_{2}$ & 0.107 & 0.090 & 0.102 & 0.085 & 0.081 & 0.096 & 0.091 & 0.077 & 0.073 & 0.073 & 0.081 & 0.081 \\
\hline
\end{tabular}


Table 3-4. Target glass compositions for Frit 503 with the outer layer SB4 EVs (in wt\%).

\begin{tabular}{|c|c|c|c|c|c|c|c|c|c|c|}
\hline Glass ID & SB4VS-22 & SB4VS-23 & SB4VS-24 & SB4VS-25 & SB4VS-26 & SB4VS-27 & SB4VS-28 & SB4VS-29 & SB4VS-30 & SB4VS-31 \\
\hline WL & 42 & 40 & 40 & 38 & 38 & 36 & 36 & 34 & 34 & 32 \\
\hline $\mathrm{Al}_{2} \mathrm{O}_{3}$ & 10.820 & 9.286 & 8.788 & 8.696 & 8.348 & 8.821 & 7.909 & 8.151 & 7.470 & 7.030 \\
\hline $\mathrm{B}_{2} \mathrm{O}_{3}$ & 8.120 & 8.400 & 8.400 & 8.680 & 8.680 & 8.960 & 8.960 & 9.240 & 9.240 & 9.520 \\
\hline $\mathrm{BaO}$ & 0.061 & 0.058 & 0.041 & 0.039 & 0.055 & 0.037 & 0.053 & 0.050 & 0.035 & 0.047 \\
\hline $\mathrm{CaO}$ & 0.882 & 1.048 & 1.048 & 0.798 & 0.996 & 0.944 & 0.756 & 0.714 & 0.714 & 0.839 \\
\hline $\mathrm{Ce}_{2} \mathrm{O}_{3}$ & 0.074 & 0.071 & 0.050 & 0.047 & 0.067 & 0.045 & 0.064 & 0.060 & 0.042 & 0.057 \\
\hline $\mathrm{Cr}_{2} \mathrm{O}_{3}$ & 0.103 & 0.098 & 0.069 & 0.066 & 0.093 & 0.062 & 0.088 & 0.083 & 0.059 & 0.078 \\
\hline $\mathrm{CuO}$ & 0.030 & 0.028 & 0.020 & 0.019 & 0.027 & 0.018 & 0.025 & 0.024 & 0.017 & 0.023 \\
\hline $\mathrm{Fe}_{2} \mathrm{O}_{3}$ & 10.165 & 9.681 & 10.571 & 9.197 & 9.644 & 8.713 & 10.217 & 8.229 & 9.650 & 9.082 \\
\hline $\mathrm{K}_{2} \mathrm{O}$ & 0.163 & 0.155 & 0.110 & 0.104 & 0.147 & 0.099 & 0.140 & 0.132 & 0.093 & 0.124 \\
\hline $\mathrm{La}_{2} \mathrm{O}_{3}$ & 0.052 & 0.050 & 0.035 & 0.034 & 0.047 & 0.032 & 0.045 & 0.042 & 0.030 & 0.040 \\
\hline $\mathrm{Li}_{2} \mathrm{O}$ & 4.640 & 4.800 & 4.800 & 4.960 & 4.960 & 5.120 & 5.120 & 5.280 & 5.280 & 5.440 \\
\hline $\mathrm{MgO}$ & 0.937 & 1.101 & 0.892 & 1.046 & 1.046 & 0.803 & 0.991 & 0.758 & 0.758 & 0.714 \\
\hline $\mathrm{MnO}$ & 2.391 & 2.058 & 2.058 & 2.163 & 2.163 & 2.049 & 1.852 & 1.749 & 1.935 & 1.821 \\
\hline $\mathrm{Na}_{2} \mathrm{O}$ & 12.459 & 12.672 & 12.672 & 12.238 & 12.238 & 11.804 & 11.031 & 11.371 & 10.898 & 9.728 \\
\hline $\mathrm{NiO}$ & 0.544 & 0.724 & 0.518 & 0.687 & 0.492 & 0.466 & 0.466 & 0.615 & 0.615 & 0.579 \\
\hline $\mathrm{PbO}$ & 0.045 & 0.043 & 0.030 & 0.029 & 0.041 & 0.027 & 0.038 & 0.036 & 0.026 & 0.034 \\
\hline $\mathrm{SO}_{4}{ }^{2-}$ & 0.533 & 0.507 & 0.507 & 0.577 & 0.482 & 0.546 & 0.546 & 0.516 & 0.431 & 0.485 \\
\hline $\mathrm{SiO}_{2}$ & 44.704 & 46.099 & 46.099 & 47.494 & 47.291 & 48.697 & 48.889 & 50.102 & 50.102 & 51.679 \\
\hline $\mathrm{ThO}_{2}$ & 0.031 & 0.030 & 0.021 & 0.020 & 0.028 & 0.019 & 0.027 & 0.025 & 0.018 & 0.024 \\
\hline $\mathrm{TiO}_{2}$ & 0.013 & 0.012 & 0.009 & 0.008 & 0.012 & 0.008 & 0.011 & 0.011 & 0.007 & 0.010 \\
\hline $\mathrm{U}_{3} \mathrm{O}_{8}$ & 3.072 & 2.925 & 3.153 & 2.995 & 2.995 & 2.633 & 2.633 & 2.680 & 2.486 & 2.522 \\
\hline $\mathrm{ZnO}$ & 0.048 & 0.046 & 0.033 & 0.031 & 0.044 & 0.029 & 0.041 & 0.039 & 0.028 & 0.037 \\
\hline $\mathrm{ZrO}_{2}$ & 0.115 & 0.110 & 0.077 & 0.074 & 0.104 & 0.070 & 0.099 & 0.093 & 0.066 & 0.088 \\
\hline
\end{tabular}


Table 3-5. Target glass compositions with Frit 503 and the outermost layer SB4 EVs (in wt\%).

\begin{tabular}{|c|c|c|c|c|}
\hline Glass ID & SB4VS-32 & SB4VS-33 & SB4VS-34 & "SB4VS-35 \\
\hline WL & 40 & 38 & 36 & 34 \\
\hline $\mathrm{Al}_{2} \mathrm{O}_{3}$ & 8.400 & 9.880 & 9.360 & 7.140 \\
\hline $\mathrm{B}_{2} \mathrm{O}_{3}$ & 8.400 & 8.680 & 8.960 & 9.240 \\
\hline $\mathrm{BaO}$ & 0.067 & 0.032 & 0.030 & 0.057 \\
\hline $\mathrm{CaO}$ & 1.200 & 1.140 & 0.720 & 0.680 \\
\hline $\mathrm{Ce}_{2} \mathrm{O}_{3}$ & 0.081 & 0.038 & 0.036 & 0.069 \\
\hline $\mathrm{Cr}_{2} \mathrm{O}_{3}$ & 0.112 & 0.053 & 0.050 & 0.095 \\
\hline $\mathrm{CuO}$ & 0.032 & 0.015 & 0.015 & 0.027 \\
\hline $\mathrm{Fe}_{2} \mathrm{O}_{3}$ & 10.800 & 9.120 & 10.080 & 8.500 \\
\hline $\mathrm{K}_{2} \mathrm{O}$ & 0.177 & 0.084 & 0.080 & 0.151 \\
\hline $\mathrm{La}_{2} \mathrm{O}_{3}$ & 0.057 & 0.027 & 0.026 & 0.048 \\
\hline $\mathrm{Li}_{2} \mathrm{O}$ & 4.800 & 4.960 & 5.120 & 5.280 \\
\hline $\mathrm{MgO}$ & 0.800 & 1.140 & 1.080 & 0.680 \\
\hline $\mathrm{MnO}$ & 2.000 & 2.280 & 1.800 & 2.040 \\
\hline $\mathrm{Na}_{2} \mathrm{O}$ & 12.800 & 10.460 & 10.120 & 11.480 \\
\hline $\mathrm{NiO}$ & 0.800 & 0.760 & 0.360 & 0.340 \\
\hline $\mathrm{PbO}$ & 0.049 & 0.023 & 0.022 & 0.042 \\
\hline $\mathrm{SO}_{4}{ }^{2-}$ & 0.800 & 0.760 & 0.720 & 0.680 \\
\hline $\mathrm{SiO}_{2}$ & 45.600 & 47.780 & 48.440 & 50.540 \\
\hline $\mathrm{ThO}_{2}$ & 0.034 & 0.016 & 0.015 & 0.029 \\
\hline $\mathrm{TiO}_{2}$ & 0.014 & 0.007 & 0.006 & 0.012 \\
\hline $\mathrm{U}_{3} \mathrm{O}_{8}$ & 2.800 & 2.660 & 2.880 & 2.720 \\
\hline $\mathrm{ZnO}$ & 0.053 & 0.025 & 0.024 & 0.045 \\
\hline $\mathrm{ZrO}_{2}$ & 0.125 & 0.060 & 0.056 & 0.106 \\
\hline
\end{tabular}


WSRC-STI-2006-00039

Revision 0

This page intentionally left blank. 


\subsection{Summary}

A total of 35 glasses have been selected for the SB4 variability study. These glasses were selected based on the frits recommended by SRNL for SB4 processing, the most recent composition projections for SB4, and a statistical approach to introduce the likely variation in SB4 composition. The glass compositions were developed to cover a range of WLs that are likely to be processed at DWPF.

These glasses will be batched and melted following standard SRNL procedures, and testing will be completed to measure the chemical durability of each glass composition. A subsequent report will document the results of the experimental portion of the SB4 variability study. 
WSRC-STI-2006-00039

Revision 0

This page intentionally left blank. 
WSRC-STI-2006-00039

Revision 0

\subsection{References}

1. Peeler, D. K., T. B. Edwards and K. M. Fox, Frit Recommendation for SB4, SRNL-PSE2006-00128, Washington Savannah River Company, Aiken, South Carolina (2006).

2. Peeler, D. K. and T. B. Edwards, Frit Development Effort for SB4: Nominal and Variation Stage Assessments, WSRC-TR-2005-00372, Revision 0, Westinghouse Savannah River Company, Aiken, South Carolina (2005).

3. Peeler, D. K. and T. B. Edwards, The Impact of the Actinide Removal Process (ARP) on the Sludge Batch 4 Projected Operating Windows, WSRC-TR-2005-00123, Revision 0, Westinghouse Savannah River Company, Aiken, South Carolina (2005).

4. Peeler, D. K. and T. B. Edwards, Frit Development Efforts for Sludge Batch 4: ModelBased Assessments, WSRC-TR-2005-00103, Revision 0, Westinghouse Savannah River Company, Aiken, South Carolina (2005).

5. Peeler, D. K. and T. B. Edwards, Model Based Assessments for the Baseline Sludge Batch 4 (Case 15C) Flowsheet, WSRC-TR-2006-00049, Revision 0, Washington Savannah River Company, Aiken, South Carolina (2006).

6. Peeler, D. K. and T. B. Edwards, Model Based Assessments for SB4 Washing Options: 1.2M Batch/0.91M Blend and 1.4M Batch/0.96M Blend, WSRC-STI-2006-00006, Revision 0, Washington Savannah River Company, Aiken, South Carolina (2006).

7. Peeler, D. K. and T. B. Edwards, High $\mathbf{B}_{2} \mathbf{O}_{3} / \mathbf{F e}_{2} \mathbf{O}_{3}$-based Frits: MAR Assessments for Sludge Batch 4 (SB4), WSRC-TR-2006-00181, Revision 0, Washington Savannah River Company, Aiken, South Carolina (2006).

8. Smith, M. E., M. E. Stone, T. M. Jones, D. H. Miller and P. R. Burket, SB4 MRF and SMRF Tests with Frits 418, 425, and 503 (U), WSRC-STI-2006-00015, Revision 0, Washington Savannah River Company, Aiken, South Carolina (2006).

9. Edwards, T. B. and D. K. Peeler, Nepheline Formation Potential in Sludge Batch 4 (SB4) and Its Impact on Durability: Selecting Glasses for a Phase 2 Study, WSRC-TR-2005-00370, Revision 0, Westinghouse Savannah River Company, Aiken, South Carolina (2005).

10. Edwards, T. B., D. K. Peeler and K. M. Fox, The Nepheline Discriminator: Justification and DWPF PCCS Implementation Details, WSRC-STI-2006-00014, Revision 0, Washington Savannah River Company, Aiken, South Carolina (2006).

11. Fox, K. M., T. B. Edwards and D. K. Peeler, Nepheline Formation Potential in Sludge Batch 4 (SB4) and Its Impact on Durability: Selecting Glasses for a Phase 3 Study, WSRCTR-2006-00053, Revision 0, Washington Savannah River Company, Aiken, South Carolina (2006).

12. Fox, K. M., T. B. Edwards, D. K. Peeler, D. R. Best, I. A. Reamer and R. J. Workman, Durability and Nepheline Crystallization Study for High Level Waste (HLW) Sludge Batch 4 (SB4) Glasses Formulated with Frit 503, WSRC-STI-2006-00009, Revision 0, Washington Savannah River Company, Aiken, South Carolina (2006). 
13. Fox, K. M., D. K. Peeler, T. B. Edwards, D. R. Best, I. A. Reamer and R. J. Workman, Nepheline Formation Study for Sludge Batch 4 (SB4): Phase 3 Experimental Results, WSRC-TR-2006-00093, Revision 0, Washington Savannah River Company, Aiken, South Carolina (2006).

14. Peeler, D. K., T. B. Edwards, D. R. Best, I. A. Reamer and R. J. Workman, Nepheline Formation Study for Sludge Batch 4 (SB4): Phase 2 Experimental Results, WSRC-TR-200600006, Revision 0, Washington Savannah River Company, Aiken, South Carolina (2006).

15. Peeler, D. K., T. B. Edwards and T. H. Lorier, Nepheline Formation Potential in Sludge Batch (SB4) Glasses, WSRC-TR-2005-00153, Revision 0, Westinghouse Savannah River Company, Aiken, South Carolina (2005).

16. Peeler, D. K., T. B. Edwards, I. A. Reamer and R. J. Workman, Nepheline Formation Study for Sludge Batch 4 (SB4): Phase 1 Experimental Results, WSRC-TR-2005-00371, Revision 0, Westinghouse Savannah River Company, Aiken, South Carolina (2005).

17. Jantzen, C. M., J. B. Picket, K. G. Brown, T. B. Edwards and D. C. Beam, Process/Product Models for the Defense Waste Processing Facility (DWPF): Part I. Predicting Glass Durability from Composition Using a Thermodynamic Hydration Energy Reaction Model (THERMO), WSRC-TR-93-672, Revision 1, Westinghouse Savannah River Company, Aiken, South Carolina (1995).

18. Washburn, F. A., Technical Task Request: Sludge Batch 4 and MCU Frit Optimization, HLW/DWPF/TTR-2004-0026, Revision 0, Westinghouse Savannah River Company, Aiken, South Carolina (2004).

19. Peeler, D. K., Task Technical \& QA Plan: Sludge Batch and MCU Frit Optimization, WSRC-RP-2004-00746, Revision 0, Westinghouse Savannah River Company, Aiken, South Carolina (2004).

20. Peeler, D. K. and T. B. Edwards, Model Based Assessments of the Final SB4 Projections Compositions Leading to the Frit Recommendation, WSRC-TR-2006-00269, Revision 0, Washington Savannah River Company, Aiken, South Carolina (2006).

21. JMP ${ }^{\mathrm{TM}}$, Ver. 5.1.2, [Computer Software] SAS Institute Inc., Cary, NC (2002).

22. JMP $^{\mathrm{TM}}$, Ver. 3.2.6, [Computer Software] SAS Institute Inc., Cary, NC (1995).

23. Taylor, A. S., T. B. Edwards, J. C. George, T. K. Snyder and D. K. Peeler, The SRNL Composition - Properties (ComPro ${ }^{\mathrm{TM}}$ ) Database, WSRC-RP-2004-00704, Revision 0, Westinghouse Savannah River Company, Aiken, South Carolina (2004).

24. Fox, K. M., D. K. Peeler and T. B. Edwards, Request for QA Approval of Nepheline Database, SRNL-PSE-2006-00053, Washington Savannah River Company, Aiken, South Carolina (2006).

25. Peeler, D. K., C. C. Herman, M. E. Smith, T. H. Lorier, D. R. Best, T. B. Edwards and M. A. Baich, An Assessment of the Sulfate Solubility Limit for the Frit 418 - Sludge Batch 2/3 System, WSRC-TR-2004-00081, Revision 0, Westinghouse Savannah River Company, Aiken, South Carolina (2004). 
WSRC-STI-2006-00039

Revision 0

26. Fox, K. M., T. B. Edwards and D. K. Peeler, Sulfate Retention in High Level Waste (HLW) Sludge Batch 4 (SB4) Glasses, WSRC-STI-2006-00038, Revision 0, Washington Savannah River Company, Aiken, South Carolina (2006). 